Chirurgia (2020) 115: 626-634

No. 5, September - October

Copyright@ Celsius

http://dx.doi.org/10.21614/chirurgia.115.5.626

\title{
The Best Approach for Patients with Stable Coronary Disease: The Importance of a Multidisciplinary Heart Team
}

\author{
Alexandru Oprea', Adrian Molnar', Sergiu Turturica', Stefan Mot' $^{2}$, Adrian lancü2, Emese Kovacs², Madalin Marc², \\ Mihai Cocoi ${ }^{2}$, Diana Sacui ${ }^{1 *}$, Catalin Trifan', Horatiu Moldovan ${ }^{3}$ \\ ${ }^{1}$ Cardiovascular Surgery Clinic, Emergency Heart Institute for Cardiovascular Diseases, Cluj-Napoca, Romania \\ ${ }^{2}$ Cardiology Clinic, Emergency Heart Institute for Cardiovascular Diseases, Cluj-Napoca, Romania \\ ${ }^{3}$ "Titu Maiorescu" University, Bucharest, Romania
}

${ }^{*}$ Corresponding author:

Diana Sacui, MD

19-21 Motilor Street, 400001

Cluj-Napoca, Romania

E-mail: diana_sacui27@yahoo.com

\section{Abbreviations:}

HT - Heart Team,

CAD - Coronary Disease,

MT - Medical Therapy,

$\mathrm{PCl}$ - Percutaneous Coronary Intervention,

CABG - Coronary Artery Bypass Grafting,

LIMA - Left Internal Mammary Artery,

LAD - Left Anterior Descendent,

DES - Drug Eluting Stents,

AV - Atrioventricular,

MT - Medical Therapy,

$\mathrm{PCl}$ - Percutaneous Coronary Intervention

CKD - Chronic Kidney Disease,

PVD - Peripheral Vascular Disease,

Cls - Confidence Intervals,

PVD - Peripheral Vascular Disease,

$\mathrm{PCl}$ - Percutaneous Coronary Intervention,

LM - Left Main,

SIHD - Stable Ischemic Heart Disease

CT - Computed Tomography.

Received: 24.09 .2020

Accepted: 27.07.2020

\section{Rezumat}

Abordarea optimă a pacienților cu boală coronariană stabilă: importanța unei "echipe a inimii" multidisciplinare

Context:O echipă a inimii multidisciplinară ("Heart Team" - HT) este considerată în prezent a fi de mare importanță pentru o evaluare completă şi precisă a pacienților cu boală coronariană stabilă. Acest studiu evaluează rolul abordării HT în selectarea celor mai bune strategii terapeutice pentru acesti pacienți.

Metode: Studiul a inclus 200 de pacienți cu boală coronariană stabilă. Şedințele HT săptămânale au constat în discuții deschise ținând cont de cele mai noi strategii terapeutice recomandate.

Rezultatele: HT au inclus opțiunile de terapie medicală (TM), intervenție coronariană percutană (PCI) sau intervenție chirurgicală. După implementarea HT, au fost evaluate rezultatele la 1, 3 şi 6 luni, în concordanță cu caracteristicile de bază inițiale.

Rezultate: Au fost implementate următoarele strategii HT: PCI $46 \%$, tratament chirurgical - $10 \%$ şi TM - 44\% dintre pacienți. La pacientii cu boală coronariană multivasculară, decizia HT a fost majoritar în favoarea tratamentului chirurgical $(\mathrm{p}=0.011)$. Ratele de supraviețire la 6 luni conform strategiei HT au fost de $96.8 \%$ pentru PCI, 95\% pentru chirurgie si $94.2 \%$ pentru TM.

Concluzii: Decizia multidisciplinară în HT este mandatorie pentru îngrijirea optimă a pacientului şi poate preveni prejudecățile legate de specialitate. In instituțiile de îngrijire terțiară ar trebui dezvoltate şi implementate protocoale interdisciplinare pentru cazurile de boală coronariană stabilă. 
Cuvinte cheie: echipa inimii, boala coronariană stabilă, strategie terapeutică, decizie multidiciplinară

\begin{abstract}
Background:A multidisciplinary Heart Team (HT) is nowadays considered to be of great importance for a complete and accurate assessment of patients with stable coronary disease (CAD). This study evaluates the role of the HT approach in the selection of best therapeutic strategies for patients with stable CAD.

Methods: The study included 200 patients with stable coronary artery disease. The weekly HT meetings consisted of open discussion taking into consideration the latest recommended therapies. HT outcome options included medical therapy (MT), percutaneous coronary intervention (PCI), or surgical intervention (CABG). Following HT implementation, the 1-, 3-, and 6-month outcomes in addition to the distribution of baseline characteristics were assessed.

Results: The following HT strategies were implemented: PCI - 46\%, CABG - 10\% and MT - 44\% of patients. Patients selected for surgical treatment were more likely to have multi-vessel coronary disease $(\mathrm{p}=0.011)$. The survival rates at 6 months according to HT strategy were $96.8 \%$ for PCI, $95 \%$ for $\mathrm{CABG}$, and $94.2 \%$ for MT.

Conclusions: The HT multidisciplinary decision is mandatory for optimal patient care and can prevent specialty biases. Tertiary care institutions should develop and implement interdisciplinary protocols for common CAD cases.
\end{abstract}

Key words: heart team, stable coronary artery disease, therapeutic strategy, multidisciplinary decision

\section{Introduction}

The evolution of the Heart Team (HT) concept since its inception just over a decade ago is substantial (1). It includes active collaboration in decision making between cardiologists and cardiac surgeons (2). There is evidence in observational studies for the safety and effectiveness of ad-hoc percutaneous coronary intervention (PCI) when compared with delayed PCI (3). However, in the presence of complex coronary artery disease (CAD), revascularization strategies can be unclear; consequently, involvement of the HT can maximize the potential for multidisciplinary input and provide enough information in order to support informed patient decision $(1,2)$.

According to the latest ESC guidelines, the Heart Team should meet on a regular basis to analyze and interpret the available diagnostic evidence, determine the need for myocardial revascularization, and assess the relative short and long-term safety and effectiveness of the percutaneous and surgical options. Ad hoc meetings of the Heart Team should facilitate and support efficient clinical workflows (4).

In addition, it was demonstrated that a multidisciplinary approach for acute coronary syndromes, especially in young patients, offers better rehabilitation chances after surgical (coronary artery bypass grafting - CABG) or interventional (PCI) procedures (5).

The need for an interdisciplinary approach is underlined by reports on (i) the underuse of revascularization procedures in $18-40 \%$ of patients with $\mathrm{CAD}$ (6) and (ii) inappropriate use of revascularization strategies with a lack of case discussions (7).

The goal of the multidisciplinary Heart Team is to offer a balanced and complementary approach to patient care by joint and shared decision making among different medical care stakeholders such as cardiac surgery and interventional cardiology (8). By exploring the multiple options available and sharing them with patients and their families where 
applicable, more optimal shared decision making is achieved, along with a tailored recommendation for therapy for a more informed and engaged patient (8).

The revascularization approaches for coronary artery disease are taken into consideration according to their advantages and/or disadvantages (8):

- Coronary Artery Bypass Grafting (CABG) has a survival benefit in more complex disease, particularly with left internal mammary artery (LIMA) use, offers a more complete revascularization, a reduction in subsequent myocardial infarction, and a reduction in need for subsequent revascularization procedures;

- PCI is less invasive, with shorter recovery, is used for treatment of focal ischemic producing lesions leaving other lesions for later (targeted revascularization), can be repeated if needed and is usually preferred by patients;

- Hybrid coronary revascularization is minimally invasive, it involves LIMA to left anterior descendent (LAD) artery bypass with long term survival benefit and placement of drug eluting stents (DES) rather than vein grafts to circumflex and right coronary artery, it needs a Heart Team approach and represents an excellent choice in patients with limited conduit availability and in patients who have difficult to approach lesions with traditional grafting (e.g., atrioventricular (AV) groove lesions with multiple branching small epicardial coronary arteries subtending significant myocardial territories).

A multidisciplinary Heart Team is nowadays considered to be of great importance for a complete and accurate assessment of patients with stable coronary disease. The decision regarding the appropriate revascularization method should involve different medical specialties such as clinical and interventional cardiology, cardiac surgery, and radiology.

This study aimed to evaluate the role of Heart Team approach in the selection of best therapeutic strategies for patients with chronic, stable cardiac ischemic disease.

\section{Material and Method}

This prospective, observational study was conducted at a single center, between January $1^{\text {st }}$ and December $31^{\text {st }}, 2019$. In our institution, Heart Team (HT) meetings focused on coronary artery disease (CAD) patients were weekly conducted.

All patients were adults ( $>18$ years-old), with 1-vessel or multi-vessel CAD; additional relevant clinical data, functional status, and patient characteristics were integrated in the final decision when determining the best option of treatment. Patients were categorized as unstable if the symptoms had triggered an acute hospital admission. From all the patients proposed for HT meetings, we excluded those with "blank" or "normal" coronary angiography (investigated for clinical presentation signs and symptoms suggestive for CAD). Meetings consisted of open discussions taking into consideration the latest recommended therapies. HT outcome classification included medical therapy (MT), percutaneous coronary intervention (PCI), or surgical intervention (coronary artery bypass grafting - CABG).

Following HT discussion and implementation, we assessed the $1^{-}, 3^{-}$, and 6 -month results and the contingent relationship with the baseline characteristics: age, sex, previous myocardial infarction (MI), previous PCI, previous CABG, diabetes mellitus, chronic kidney disease (CKD), peripheral vascular disease (PVD), extent of coronary disease (1vessel / multi- vessel disease).

\section{Statistical Analysis}

Categorical data are presented as counts and percentages, and comparison between groups performed using chi-square test; continuous data are presented as mean $\pm \mathrm{SD}$, and analysis was performed using 1-way ANOVA test. For selected HT strategy in relationship with patients' baseline characteristics, the odds ratios (ORs) with 95\% confidence intervals (CIs) are calculated. Statistical significance is defined by a predetermined cutoff for probability (p-value) of 0.05 . 


\section{Results}

\section{A. Patient selection and HT meeting characteristics}

Patient selection and HT meeting characteristics are shown in the flow diagram illustrated in Fig. 1 .

\section{B. HT Patients demographics}

HT Patients Demographics are presented in Table 1.

In the group of patients discussed by the $\mathrm{HT}$, the average age was $65 \pm 10$ years, and $66.6 \%$ were males.

More than half $(65 \%)$ of the patients had multi-vessel coronary disease, $45.5 \%$ of all patients had undergone a previous PCI procedure, and half of the patients had a history of MI.

When compared to the entire study group, patients referred to surgery were more likely to have had a previous myocardial infarction $\mathrm{p}=0.088$ ) and a significantly lower rate of previous PCI $(p=0.078)$; none of the patients included in the CABG group had single-vessel $\mathrm{CAD}$, showing significant statistical difference when compared with the overall patients group $(\mathrm{p}=0.011)$.
Otherwise, there were no significant demographic differences between patients who were selected to undergo PCI or MT, and the overall cohort of patients.

\section{Preferred HT strategy}

For the studied patients, the HT strategy was discussed and implemented as shown in Fig. 2.

Following HT discussion and implementation, the baseline characteristics associated with a preferred HT recommendation were assessed (Table 2).

For patients with a history of peripheral vascular disease (PVD), diabetes and previous CABG, there were no significant differences between HT outcomes.

In the presence of CKD, patients were less likely to receive PCI (OR, 0.91; 95\% CI, 0.34$2.42 ; \mathrm{p}=0.855)$ or MT (OR, $0.62 ; 95 \%$ CI, 0.22 1.73; $\mathrm{p}=0.365)$, and more likely to undergo CABG (OR, 2.96; 95\% CI, 0.87-10.08; $\mathrm{p}=0.082$ ).

Patients with single-vessel coronary disease were less likely than patients with multi-vessel coronary disease to receive CABG (OR, 0.06, 95\% CI, 0.004-1.06; $\mathrm{p}=0.055)$, compared to medical therapy (OR, 1.96; 95\% CI, 1.03-3.75; $\mathrm{p}=0.041$ ).
Figure 1. Flow diagram showing the details of patient selection

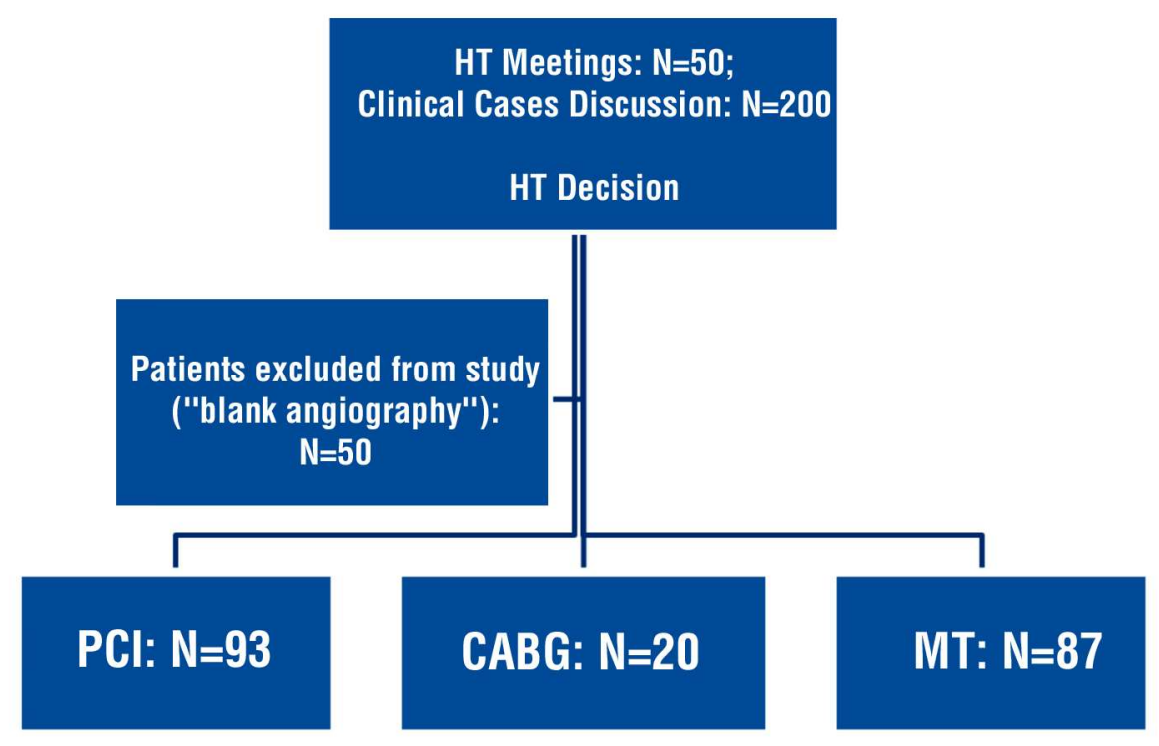

$\mathrm{HT}$ = heart team; $\mathrm{PCl}=$ percutaneous coronary intervention; $\mathrm{CABG}=$ coronary artery bypass grafting; $\mathrm{MT}=$ medical therapy; $\mathrm{N}=$ number of patients 
Table 1. Demographics of the Patients Identified From the 50 Heart Team Meetings and the statistical comparison between the three subgroups vs the overall group of patients

\begin{tabular}{|c|c|c|c|c|c|c|c|}
\hline Demographics & $\begin{array}{l}\text { Overall, } \\
\mathrm{N}=200\end{array}$ & $\begin{array}{c}\mathrm{PCl}, \\
\mathrm{N}=93\end{array}$ & $\begin{array}{c}\text { P value } \\
\text { (PCI vs Overall) }\end{array}$ & $\begin{array}{l}\text { CABG, } \\
N=20\end{array}$ & $\begin{array}{c}\text { p value } \\
\text { (CABG vs Overall) }\end{array}$ & $\begin{array}{l}\mathrm{MT}, \\
\mathrm{N}=87\end{array}$ & $\begin{array}{c}\text { p value } \\
\text { (MT vs Overall) }\end{array}$ \\
\hline Age, y (average $\pm S D$ ) & $64.7 \pm 10.2$ & $64.6 \pm 9.4$ & 0.914 & $63.7 \pm 7.6$ & 0.660 & $65.1 \pm 11.6$ & 0.782 \\
\hline Sex, Male (N, \%) & $133(66.6 \%)$ & $63(67.7 \%)$ & 0.764 & $17(85 \%)$ & 0.125 & $53(60.9 \%)$ & 0.545 \\
\hline Previous MI (N, \%) & $100(50 \%)$ & $45(48.4 \%)$ & 0.343 & $14(70 \%)$ & 0.088 & $41(47.1 \%)$ & 0.427 \\
\hline Previous PCI (N, \%) & $91(45.5 \%)$ & $42(45.2 \%)$ & 0.986 & $5(25 \%)$ & 0.078 & $44(50.6 \%)$ & 0.784 \\
\hline Previous CABG (N, \%) & $9(4.5 \%)$ & $3(3.2 \%)$ & 0.431 & $1(5 \%)$ & 0.862 & $5(5.7 \%)$ & 0.635 \\
\hline Diabetes mellitus (N, \%) & $60(30 \%)$ & $32(34.4 \%)$ & 0.789 & $5(25 \%)$ & 0.237 & $23(26.4 \%)$ & 0.369 \\
\hline Chronic kidney disease (N, \%) & $18(9 \%)$ & $8(8.6 \%)$ & 0.773 & $4(20 \%)$ & 0.118 & $6(6.9 \%)$ & 0.178 \\
\hline $\begin{array}{l}\text { Peripheral vascular disease } \\
(\mathrm{N}, \%)\end{array}$ & $45(22.5 \%)$ & $18(19.3 \%)$ & 0.321 & $7(35 \%)$ & 0.642 & $20(23 \%)$ & 0.875 \\
\hline $\begin{array}{l}\text { Coronary disease }-1 \text { vessel } \\
(\mathrm{N}, \%)\end{array}$ & $50(25 \%)$ & $22(23.6 \%)$ & 0.564 & $0(0 \%)$ & 0.011 & $28(32.2 \%)$ & 0.371 \\
\hline $\begin{array}{l}\text { Coronary disease - multiple } \\
\text { vessel }(\mathrm{N}, \%)\end{array}$ & $150(75 \%)$ & $71(76.4 \%)$ & 0.803 & $20(100 \%)$ & 0.011 & $59(67.8 \%)$ & 0.229 \\
\hline
\end{tabular}

$\mathrm{PCl}=$ percutaneous coronary intervention; $\mathrm{CABG}=$ coronary artery bypass grafting; $\mathrm{MT}=$ medical therapy; $\mathrm{N}=$ number of patients; $\mathrm{Ml}=$ myocardial infarction

\section{HT Clinical outcomes}

For the entire group of patients with stable CAD following HT discussion and implementation, survival rate was $98.5 \%$ (197 of 200) at 1 month, $97.5 \%$ (195 of 200) at 3 months, and $95.5 \%$ (191 of 200$)$ at 6 months.

30-day survival rate according to treatment option was $97.7 \%$ (85 of 87 ) in the MT group, $98.9 \%$ (92 of 93) in the PCI group, and $100 \%$ in the CABG group (20 of 20).

At 3 and 6 months, survival rate stratified according to treatment strategy was $96.5 \%$ (84 of 87 ) and $94.2 \%$ (82 of 87) in the MT group, 97.8\% (91 of 93) and $96.8 \%$ (90 of 93) in the PCI group, and 100\% (20 of 20) and 95\% (19 of $20)$ in the CABG group, respectively.

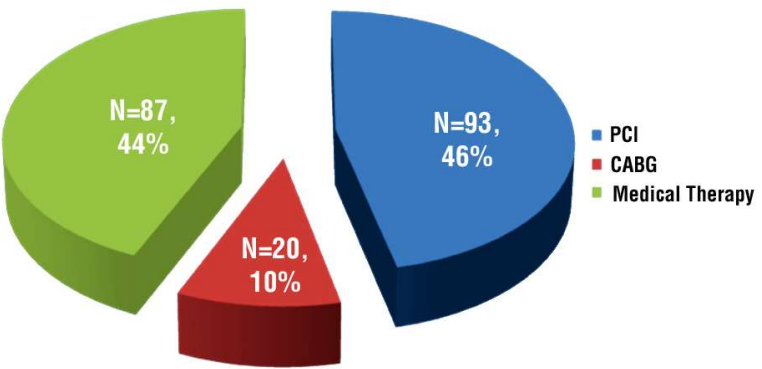

Figure 2. The HT strategy

$\mathrm{PCl}=$ percutaneous coronary intervention;

$\mathrm{CABG}=$ coronary artery bypass grafting; $\mathrm{N}=$ number of patients

Thus, the mortality risk was not significantly higher in the group of patients selected for MT compared with those selected to receive $\mathrm{CABG}$ and $\mathrm{PCI}(\mathrm{p}=0.455)$.

Table 2. Relationships Between Baseline Characteristics and HT Strategy (data are presented as odds ratios $(95 \% \mathrm{Cls})$ and P-values):

\begin{tabular}{|c|c|c|c|}
\hline Variable & PCI & CABG & MT \\
\hline Previous CABG & $\begin{array}{c}0.56(0.14-2.31) \\
P=0.423\end{array}$ & $\begin{array}{c}1.13(0.13-9.54) \\
P=0.909\end{array}$ & $\begin{array}{c}1.66(0.43-6.38) \\
P=0.459\end{array}$ \\
\hline Chronic kidney disease & $\begin{array}{c}0.91(0.34-2.42) \\
P=0.855\end{array}$ & $\begin{array}{c}2.96(0.87-10.08) \\
P=0.082\end{array}$ & $\begin{array}{c}0.62(0.22-1.73) \\
P=0.365\end{array}$ \\
\hline Peripheral vascular disease & $\begin{array}{c}0.71(0.36-1.39) \\
P=0.322\end{array}$ & $\begin{array}{c}2.01(0.75-5.39) \\
P=0.165\end{array}$ & $\begin{array}{c}1.05(0.54-2.05) \\
P=0.884\end{array}$ \\
\hline Diabetes mellitus & $\begin{array}{c}1.48(0.81-2.77) \\
P=0.206\end{array}$ & $\begin{array}{c}0.76(0.26-2.19) \\
P=0.608\end{array}$ & $\begin{array}{c}0.74(0.39-1.37) \\
P=0.335\end{array}$ \\
\hline Coronary disease - 1 vessel & $\begin{array}{c}0.87(0.46-1.66) \\
P=0.682\end{array}$ & $\begin{array}{c}0.06(0.004-1.06) \\
P=0.055\end{array}$ & $\begin{array}{c}1.96(1.03-3.75) \\
P=0.041\end{array}$ \\
\hline
\end{tabular}

$\mathrm{PCl}=$ percutaneous coronary intervention; $\mathrm{CABG}=$ coronary artery bypass grafting; $\mathrm{MT}=$ medical therapy 
Survival rates according to HT strategy are shown in Fig. 3.

\section{Discussion}

In this 1-year prospective, observational study that evaluated patients with stable CAD that underwent HT discussion and implementation, the main findings were as follows:

1. Patients included had a mean age of 65 , half of them had a history of myocardial infarction, and $75 \%$ of patients had multi-vessel CAD;

2. Patients had increased odds of receiving surgery in the presence of CKD;

3. Patients with multi-vessel CAD had increased odds of receiving PCI or CABG;

4. There were increased odds of receiving MT in patients with single-vessel disease; and

5. There was no significant difference in survival rate between CABG and PCI groups.

We found no significant difference regarding the age of patients selected for either therapeutic strategy, even if there are current studies supporting better long-term outcomes associated with CABG. There was also a clear tendency for surgical therapy recommendation in patients who present associated CKD, even if other studies shown that in these cases MT was the preferred strategy (2). However, as the extent of coronary disease increased, patients were more likely to receive CABG and PCI than MT.

We found improved clinical outcomes associated with PCI and CABG strategies when compared with medical therapy, although recent trials have shown no difference between MT and PCI with respect to long-term outcomes.

There was no significant difference in 6months survival between PCI and CABG groups, even if forthese patients measured decision making by HT discussion and implementation lead to enhanced overall survival.

In the studied patients, we have shown the $\mathrm{HT}$ to be effective. As familiarity grows with the HT approach, we hope that there will be an

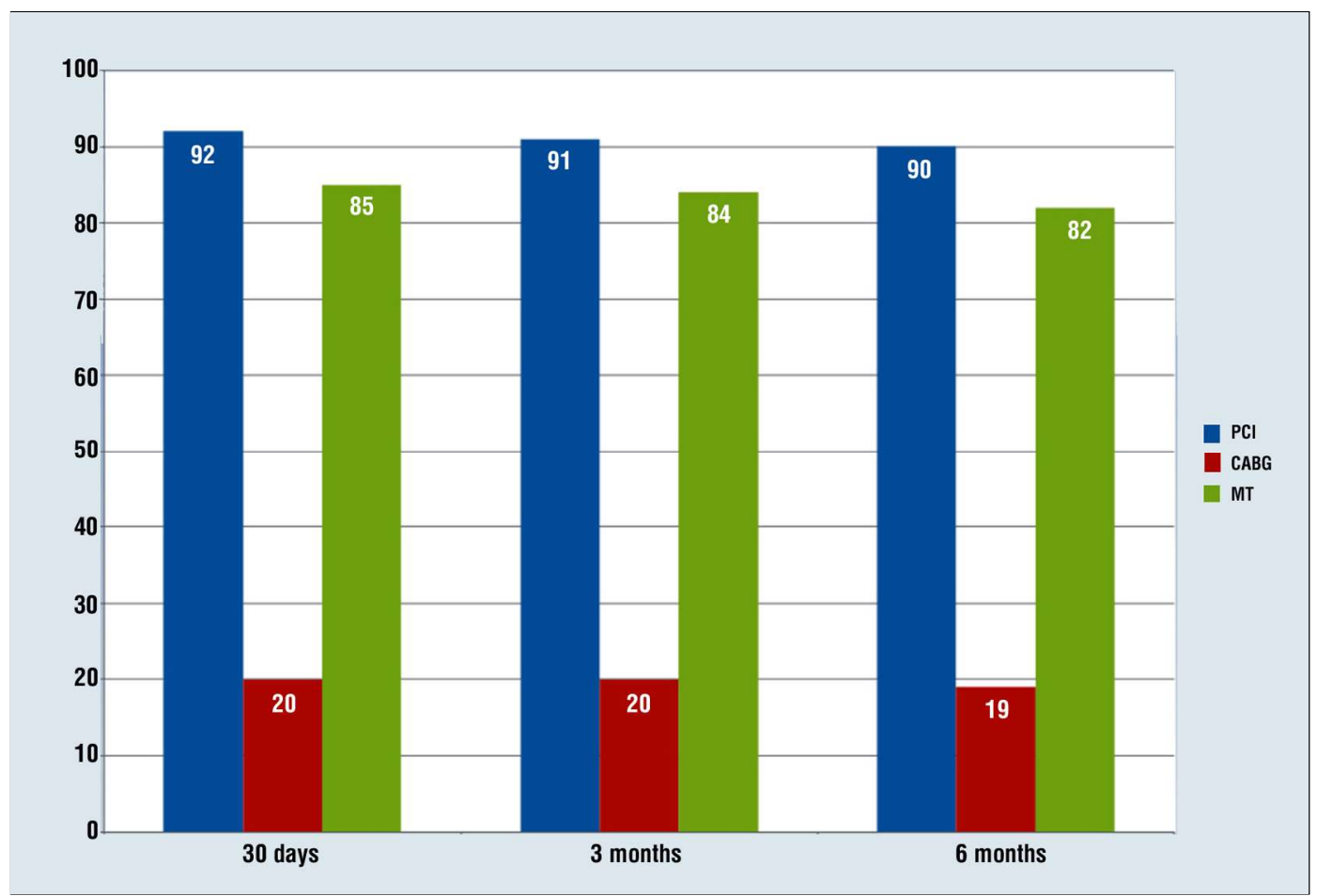

Figure 3. Survival rates according to HT strategy:

$\mathrm{PCI}=$ percutaneous coronary intervention; $\mathrm{CABG}=$ coronary artery bypass grafting; $\mathrm{MT}=$ medical therapy 
increased tendency for physicians to use the HT as the default decision making strategy for patients with stable or complex CAD. Additionally, as choices and treatments are now more complex, "the future of cardiology jobs may rest in Heart Teams." (8). Even if Romania is one of the high cardiovascular risk European countries according to data from the last ESC guideline for prevention of CVD, there are only a limited number of national epidemiological studies which estimate the prevalence and future trends of cardiovascular risk factors in the Romanian population (9).

In recent years, minimally invasive cardiac surgery, robotically assisted coronary bypass surgery and hybrid coronary revascularization procedures are emerging; consequently, we are witnessing a continuous changing in the management of various valvulopathies and ischemic coronary disease (10).

All Guidelines regarding Heart Team activation carry a Level $\mathrm{C}$ indication and emphasize the very future and the needs of this new Team: randomized controlled trials proving solid benefits in an evidence-based world (11). Obviously, a final therapy decision yielded through a discussion gathering information from more specialists is more accurate and generates better cardiovascular outcomes (12).

Since 2010, there are specific solid indications (class I recommendation) to discuss and treat complex coronary patients through a Heart Team solution (13). Also, each European Society of Cardiology (ESC) Guideline has dedicated recommendations to evaluate complex situations inside a Heart Team (12).

The treatment options for stable, complex coronary artery disease include coronary artery bypass grafting (CABG), percutaneous coronary intervention (PCI), or medical therapy. Over the recent years, multidisciplinary decision-making has gained more emphasis in the selection of the most optimal strategy for individual patients (14).

The Heart Team approach can cause delays in decision-making and treatment, inefficiency in care, and increased expense by foregoing 'ad hoc' decisions. Heart Team meetings furthermore require an investment in time of surgeons, cardiologists, and ancillary personal, thereby increasing direct costs (14). Also, there have been concerns that multidisciplinary decision-making can be based on autocratic individuals that consider themselves highest on the hierarchical tree (15).

In patients with left main (LM) lesions and stable ischemic heart disease (SIHD), surgery (CABG) is recommended if associated 2 or 3 vessels disease is present, the Syntax score is $\geq 33$, and the surgical risk is not high (16). Otherwise, all cases should be discussed in HT, and individualized therapeutic decision must be implemented.

An HT approach to decision-making provides transparency for decision-making in the treatment of patients with CAD. It is a robust and usually reproducible process (17).

According to joint guidelines for the European Society of Surgery, patients with stable coronary artery disease, those with $1^{-}$- or 2 -vessel disease, not involving the proximal left anterior descending artery, should be offered percutaneous coronary intervention.

More extensive disease involving the left main stem or proximal left anterior descending, or those with 3-vessel disease should be considered for coronary artery bypass grafting in the first instance. Specific mention is made of high-risk groups, including patients with chronic kidney disease, left ventricular failure, and diabetes, in whom surgery is the preferred option (18).

In recent years, the European Society of Cardiology (ESC) and the European Association for Cardio-Thoracic Surgery (EACTS) recommend formation of Heart Teams for the approach of complex, high-risk cardiovascular diseases that need a multi-disciplinary assessment for optimal therapeutic choice (like in acute aortic type A dissection), or for establishing the best timing for surgery (like in congenital heart diseases and endocarditis). Some studies shown the importance of collaboration between cardiologist, pathologist and cardiac surgeon in approaching 
rarely seen cases, like "aortitis syndrome in combination with hypertension and atherosclerosis in association with ascending aortic dissection" (19). In pediatric cardiac surgery, a multidisciplinary team should decide the intervention type (percutaneous or surgical) for patients with coarctation of aorta or persistent arterial duct, while in patients with Tetralogy of Fallot, the timing of surgical correction is proven to influence the "psycho" logical development and cognitive outcome determined by the preoperative chronic cerebral hypoxia" (20); in these cases, the complementary psychological assessment was very useful. Regarding the endocarditis subject, the best operatory moment is still under debate, considering the higher risk for early post-operative complications and mortality in cases where emergency intervention is performed. In endocarditis patients, the imaging techniques (especially transesophageal echocardiography - TEE and computed tomography - CT), performed by experimented specialists, are of great importance in order to identify possible complications that could influence the surgical timing $(21,22)$. Also, the Heart Team could be very valuable in rare associations between cardiac pathologic conditions and other complicated diseases. In such cases with high risk, complex patients, a strong collaboration between all specialties is needed to overcome all of the limitations of the patient's co-morbidities (23).

\section{Conclusions}

The Heart Team multidisciplinary decision is mandatory for optimal patient care and can prevent specialty biases.

Tertiary care institutions should develop and implement interdisciplinary protocols for common CAD cases; however, the complex cases should be assessed individually and with regard to the specific findings for each patient, in order to avoid the overlook of some important information.

At the moment, the central role of Heart Team in the improvement of therapeutic procedures and patient selection is also emphasized by the continuously developing strategies of care in cardiovascular disease.

\section{Ethical Policy}

During this study, the procedures followed were in accordance with the ethical standards of the responsible committee on human experimentation (institutional and national) and with the Helsinki Committee for Human Rights. Consequently, the study obtained the approval from The Ethical Commission of our institution.

\section{Conflict of Interest}

None declared for all authors.

\section{Acknowledgements}

This work was supported by the Romanian Academy of Medical Sciences and European Regional Development Fund, MySMIS 107124: Funding Contract 2/AXA1/ 31.07.2017.

\section{References}

1. Serruys PW, Morice MC, Kappetein AP, Colombo A, Holmes DR, Mack MJ, et al. Percutaneous coronary intervention versus coronary-artery bypass grafting for severe coronary artery disease (published correction appears in N Engl J Med. 2013; 368(6):584)

2. Patterson T, McConkey HZR, Ahmed-Jushuf F, Moschonas K, Nguyen H, Karamasis GV, et al. Long-Term Outcomes Following Heart Team Revascularization Recommendations in Complex Coronary Artery Disease. J Am Heart Assoc. 2019;8(8):e011279.

3. Blankenship JC, Gigliotti OS, Feldman DN, Mixon TA, Patel RAG, Sorajja $\mathrm{P}$, et al. Ad Hoc percutaneous coronary intervention: a consensus statement from the society for cardiovascular angiography and interventions. Cathet Cardiovasc Interv. 2012;81:748-758.

4. Neumann F-J, Sousa-Uva M, Ahlsson A, Alfonso F, Banning AP, Umberto Benedetto U, et al. 2018 ESC/EACTS Guidelines on myocardial revascularization. Eur Heart J. 2019;40(2):87-165.

5. Anchidin OI, Nemes A, Molnar A, Rosianu A, Rosianu SH, Pop D. Are cardiovascular rehabilitation programs implemented in young patients with acute coronary syndromes following revascularization procedures? Balneo. 2020; 1:133-140.

6. Filardo G, Maggioni AP, Mura G, Valagussa F, Valagussa L, Schweiger $C$, et al. The consequences of under-use of coronary revascularization; Results of a cohort study in Northern Italy. Eur Heart J. 2001;22(8):654-62

7. Yates MT, Soppa GK, Valencia O, Jones S, Firoozi S, Jahangiri M. Impact of European Society of Cardiology and European Association for Cardiothoracic Surgery Guidelines on Myocardial Revascularization on the activity of percutaneous coronary 
intervention and coronary artery bypass graft surgery for stable coronary artery disease. J Thorac Cardiovasc Surg. 2014;147(2): 606-10. Epub 2013 Feb 10.

8. Holmes DR, JR, Rich JB, Zoghbi WA, Mack MJ. The Heart Team of Cardiovascular Care. J Am Coll Cardiol. 2013;61(9):903-7.

9. Popa LE, Petresc B, Catana C, Moldovanu CG, Feier DS, Lebovici A, et al. Association between cardiovascular risk factors and coronary artery disease assessed using CAD-RADS classification: a cross-sectional study in Romanian population. BMJ Open. 2020;10(1): e031799.

10. Easterwood RM, Bostock IC, Nammalwar S, McCullough JN, Iribarne A. The evolution of minimally invasive cardiac surgery: from minimal access to transcatheter approaches. Future Cardiol. 2018:14(1):75-87.

11. Coylewright M, Mack MJ, Holmes DR, O'Gara PT. A call for an evidence-based approach to the heart team for patients with severe aortic stenosis. J Am Coll Cardiol. 2015;65(14):1472-80.

12. Burlacu A, Covic A, Cinteza M, Lupu PM, Deac R, Tinica G. Exploring Current Evidence on the Past, the Present, and the Future of the Heart Team: A Narrative Review. Cardiovasc Ther. 2020 Jan 4;2020:9241081. eCollection 2020.

13. Taggart DP, Boyle R, de Belder MA, Fox KA. The 2010 ESC/EACTS guidelines on myocardial revascularization. Heart. 2011;97(6):445446.

14. Head SJ, Kaul S, Mack MJ, Serruys PW, Taggart DP, Holmes DR, et al. The rationale for Heart Team decision-making for patients with stable, complex coronary artery disease. Eur Heart J. 2013; 34(32):2510-8

15. Taylor C, Munro AJ, Glynne-Jones R, Griffith C, Trevatt P, Richards M, Ramirez AJ. Multidisciplinary team working in cancer: what is the evidence? BMJ. 2010;340:c951.

16. Al-Attar N, Folliguet T. The Heart Team to assess risk in coronary artery disease. E-Journal of Cardiology Practice. 2013 Mar; 11
(17). Available from: https://escardio.org/Journals/E-Journal-ofCardiology-Practice/Volume-11/The-Heart-Team-to-assess-risk-incoronary-artery-disease.

17. Longa J, Luckraz H, Thekkudan J, Maherb A, Norellb M. Heart team discussion in managing patients with coronary artery disease: outcome and reproducibility. Interact Cardiovasc Thorac Surg. 2012;14(5):594-8.

18. Radu S, Floria M, Baroi GL, Bocinca C, Ouatu A, Tanase DM, et al. Heart Team in cardiovascular disease-between utility and limits. Romanian Journal of Cardiology. 2016;26(4):440-9.

19. Bedeleanu D, Coman C, Encica S, Hagiu R, Molnar A, Căpâlneanu R. Stanford type A aortic dissection in a hypertensive patient with atherosclerosis of aorta and aortitis. Echocardiography. 2000; 17(2):181-5.

20. Chira M, Ciotlaus DF, Tinica G, Manole S, Sacui DM, Molnar A. Early Repair Benefits in Cognitive Development of Patients with Tetralogy of Fallot. Review of Research and Social Intervention. 2017;57: 78-88.

21. Molnar A, Sacui D, Manole S, Radulescu A, \& Beyer R. The value of transthoracic and transesophageal echocardiography for the diagnosis of the native aortic infective endocarditis valve complications: a case report and literature review. Med Ultrason. 2016; 18(2):253-6.

22. Molnar A, Beyer R, Florian S, Muresanu DF, Trifan C, Muresan I, et al. Drainage of cerebral abscesses prior to valve replacement in stable patients with acute left-sided infective endocarditis. CNS Neurol Disord Drug Targets. 2015;14(4):534-9.

23. Moldovan H, Popescu D, Buliga T, Filip A, Antoniac I, Gheorghita D, et al. Gastric Adenocarcinoma Associated with Acute Endocarditis of the Aortic Valve and Coronary Artery Disease in a 61-Year-Old Male with Multiple Comorbidities-Combined Surgical Management - Case Report. Medicina (Kaunas). 2019;55(6):242. 